УДК: 130.33(477)

DOI:

Лариса Костюк, кандидат філософських наук, доиент кафедри культурології та мистецької освіти Дрогобицького державного педагогічного університету імені Івана Франка

\title{
ЕТНОМЕНТАЛЬНИЙ АСПЕКТ УКРАЇНСЬКОЇ ХУДОЖНЬОЇ КУЛЬТУРИ 60-Х РОКІВ ХХ СТОЛІТТЯ
}

Автор статті акцентує увагу на актуальності звернення до проблеми етноментального аспекту української художньої культури 60-х років минулого століття - так званого покоління шістдесятників. Своєю метою представники мистецького руху “иістдесятництва” вбачали поєднання західноєвропейських та національних традицій, винесення украӥнського мистецтва на світову художню арену. Уякості основного завдання автор вбачає виявлення причинно-наслідкових зв 'язків між украӥнською художньою культурою 60-х років ХХ століття та ментальністю як способом реалізацї своєї культурної ідентичності.

Ключові слова: художня культура; ментальність; “иістдесятництво”; нонконформізм.

Jim. 11.

Larysa Kostyuk, Ph.D.(Philosophy), Associate Professor of the Culturology and Artistic Education Department Drohobych Ivan Franko State Pedagogical University

\section{ETHNOMETAL ASPECT OF UKRAINIAN ART CULTURE OFTHE 60s OFTHE 20th CENTURY}

The author considers the topicality of the appeal to the problem of ethnomental aspect of Ukrainian art culture of the 1960s-socalled generation of sixties. The goal of the representatives of the artistic movement of the "sixties" was the combination of Western European and national traditions and the presentation of Ukrainian art at the world art scene. In the author's opinion, the main task is finding out the causal connections between Ukrainian art culture of the 60s of the 20th century and mentality as the way of cultural identity realization.

Conditions of the development of Ukrainian art culture in the 60s of the 20th century positively influenced the spiritual atmosphere, stimulated creative and cultural life, furthered the increase of interest in the history of Ukraine, its culture and traditions, customs, language. The basis of ideological principles of the "sixties" is the recognition of freedom in all its manifestations: freedom of conscience, freedom of thought, freedom of nation. Ukrainian folklore was one of the sources of creativity. The artists actively adopted and rethought folk motives and images, used folk-song means and techniques of image creation. In spite of the state directive to form the thesis about the equality of all "Soviet people" in the public consciousness, the specifics of Ukrainian mentality with its main directive of "cordocentricity" caused an appeal to the irrational, unconscious element in the very phenomenon. Mental factors are the criterion of one ethnic group's interest in the acquiring cultural and intellectual heritage of other ethnic group for a complete social and cultural integration into the civilized space. They are also a means of personal spiritual enrichment. Therefore, the entry of Ukraine into the world civilized circle does not deny Ukrainian identity, it occurs through the integration of ethnic and universal human values and meanings.

Keywords: the art culture; mentality; "sixties"; recusance.

П остановка проблеми. Своєрідною моральною опозицією тоталітарному режиму став культурницький рух молодої інтелігенції 60-х років XX століття, яка виступала проти русифікації, ущемлення демократії, прав людини, недотримання існуючої Конституції, за свободу в питаннях художньої творчості. Зокрема, підвищений інтерес відзначається щодо художньо-естетичних феноменів, які визначають український народ як націю - до його ментальності, самобутності, місця у світовому просторі. Ментальність етносу явище, яке не можна репрезентувати як суто мисленнєві чи психологічні риси, бо вони $\epsilon$ невід'ємними від форм суспільної життєдіяльності, що не лише зумовлюють виникнення таких рис, а й слугують підгрунтям постійного їх самовідтворення, а також $є$ невід'ємними від світу символічних культурних форм й значень, в яких ці риси відтворюються. Ментальність існує невід'ємно від історикокультурного буття етносу - яке (буття) створює й відтворює певну "модель" бажаного для нього типу особистості.

Для української художньої культури характерна “хвилеподібність" процесу становлення, утвердження та відродження національної традиції у творчості митців. Активно вивчаючи творчість європейських митців, їхні сучасники в Україні прагнули культурного зв' язку із Заходом, єдиним 
шляхом до якого була репрезентація власного, національного художнього доробку на світовому рівні. Саме таке бачення можливостей розвитку української культури говорить про важливість їі етноментальних характеристик. Розуміючи структуру як сукупність історичних зв'язків між виділеними частинами цілого, що забезпечує його єдність, існування і функціонування певної системи для збереження основних властивостей та функцій при різноманітних її змінах, визначаємо внугрішню форму (зміст) ментальності як спосіб встановлення сутнісних, відносно стійких зв'язків між іiі елементами. Системоутворювальними чинниками ментальності $\epsilon$ такі аспекти: філогенетична спадковість; готовність до реакції на зовнішній і внутрішній світ людини та організація такої готовності; зв'язок готовності 3 попереднім індивідуальним досвідом; спрямований і динамічний вплив готовності на активність і поведінку.

Причиною великих збурень і духовних пошуків, спричинених лібералізацією, що вилилось у нестримне оновлення мистецтва (авангардизм у літературі, живописі, скульптурі тощо) стали вже перші хвилі хрущовської “відлиги”. Спроби демократизації суспільства породжували в душах людей сподівання на українське відродження зразка 20-х років, коли в художній культурі бурхливо створювалися мистецькі школи, напрями, пристрасні літературні дискусії. Саме в 60-х роках молоде покоління письменників, назване шістдесятниками, почало орієнтуватися не на сучасних їм класиків соціалістичного реалізму, а на кращі мистецькі взірці початку XX ст. Соціальні катаклізми, які і лягли в основу їхньої творчості (війна, відбудова, репресії), вплинули на формування світогляду, сприяли масштабності мислення, відчуття причетності до історії та відповідальності за долю свого народу.

Культурницький рух молодої інтелігенції, зокрема підвищений інтерес до художньоестетичних феноменів, що визначають український народ як націю - до його ментальності, самобутності, місця у світовому просторі став своєрідною моральною опозицією тоталітарному режиму. Водночас в українській інтелектуальній традиції питання ментальності розвивається не лише в теоретичному аспекті, а у напрямку вирішення життєво важливих проблем етнокультурного буття спільноти.

Аналіз основних досліджень і публікацій. Джерелами вивчення означеної проблеми $є$ насамперед публікації самих шістдесятників, які дають можливість глибше зрозуміти представників даного історичного періоду (М. Коцюбинська,
Є. Сверстюк, І. Світличний, Л. Танюк та ін.). Обгрунтуванню ідейних настанов та безпосередньо художній творчості молодої інтелігенції 60-х років присвячено значну кількість наукових праць істориків, літературознавців, мистецтвознавців, культурологів. Висвітленню ідейних засад “шістдесятництва” в історикокультурному контексті присвячені публікації Н. Краснянської [7], Р. Корогодського [4], інших науковців.

Окремі питання досліджуваної проблеми розглядають усвоїх працях С. Білокінь [2], Л. Гонтова [5], С. Мезіна [9], Г.П. Погребняк [10], деякі інші дослідники. Проте проблема етноментального аспекту українського авангарду 60-х не набула належного наукового висвітлення.

Метою статті $\epsilon$ виявлення причиннонаслідкових зв'язків між українською художньою культурою 60-х років XX століття та ментальністю як способом реалізації своєї культурної ідентичності.

Виклад основного матеріалу. Закріплення в науці поняття “ментальність” викликане необхідністю охарактеризувати ті невідомі чинники історичного процесу, ті фактори колективної свідомості, які детермінують поведінку людських мас. За визначенням філософського енциклопедичного словника: "Ментальність (від лат. mens (mentis) - спосіб мислення, склад душі) - характеристики специфіки сприйняття та тлумачення світу в системі духовного життя того чи іншого народу, нації, соціальних суб'єктів, що уособлюються певними соціокультурними феноменами" $[11,369]$.

Ментальність етносу - явище, яке не можна репрезентувати як суто мисленнєві чи психологічні риси, бо вони є невід'ємними від форм суспільної життєдіяльності, що не лише зумовлюють виникнення таких рис, а й слугують підгрунтям постійного їх самовідтворення, а також $\epsilon$ невід'ємними від світу символічних культурних форм й значень, в яких ці риси відтворюються. Ментальність існує невід'ємно від історикокультурного буття етносу - яке (буття) створює й відтворює певну “модель” бажаного для нього типу особистості.

Для української художньої культури характерна “хвилеподібність” процесу становлення, угвердження та відродження національної традиції у творчості митців: зокрема знаковими $є$ доба українського бароко, період "Розстріляного відродження”, українське “шістдесятництво”. Можливо, саме така “уривчастість” сприяє більш яскравому прояву, виявленню могутніх осередків, названих “золотими нитками історії” $[8,250]$. 
Активно вивчаючи творчість європейських митців, шістдесятники прагнули культурного зв'язку із Заходом, єдиним шляхом до якого була репрезентація власного, національного художнього доробкуна світовому рівні. Виступаючи на захист національної мови і культури, свободи художньої творчості, офіційному догматизмові митці протиставляли свободу творчого самовираження, культурний плюралізм, пріоритет загальнолюдських цінностей над класовими. Вони відновили традиції класичної дореволюційної інтелігенції, якій були притаманні прагнення до духовної незалежності, політична відчуженість, ідеали громадянського суспільства та служіння народові.

Саме таке бачення можливостей розвитку української культури говорить про важливість їі етноментальних характеристик. Розуміючи структуру як сукупність історичних зв'язків між виділеними частинами цілого, що забезпечує його єдність, існування і функціонування певної системи для збереження основних властивостей та функцій при різноманітних її змінах, визначимо внутрішню форму ментальності як спосіб встановлення сутнісних, відносно стійких зв'язків між іiі елементами. Системоугворювальними чинниками ментальності є такі аспекти: філогенетична спадковість; готовність до реакції на зовнішній і внутрішній світ людини та організація такої готовності; зв'язок готовності з попереднім індивідуальним досвідом; спрямований і динамічний вплив готовності на активність і поведінку.

Беручи до уваги праці М. Костомарова, М. Грушевського, В. Липинського, Ю. Липи, О. Кульчицького та ін., визначимо головні настанови етнічної ментальності українців: індивідуалізм, що проявляється у різних формах прагнення до свободи; “кордоцентризм”, що проявляється у сентименталізмі, любові до природи, естетизмі народного життя, культуротворчості; “антеїзм” у якому розкривається така риса, як “зрощеність”, “злитість” людини з природою, лірично-поетичне, пісенне переживання рідної природи $[8,39]$.

Естетична незалежність шістдесятників, що базувалася на двох духовно-інформаційних потоках, виростала саме 3 потужних національних та світових традицій та у контексті світових національно-визвольних процесів $[7,96]$. Зокрема духовною атмосферою шістдесятників стала поезія В. Вітмена, Г. Аполлінера,Шелюара, Ф.Г. Лорки, П. Неруди, емоційно напружена проза Дж. Джойса, Е. Хемінгуея, Е.-М. Ремарка, Г. Белля та ін. Другий аспектом були твори реабілітованих українських письменників, переважно представників “розстріляного відродження”'(В. Чумак, Є. Плужник, М. Зеров, М. Драй-Хмара,О. Слісаренко, Г. Косинка й ін.). Важливим культурним джерелом залишалася народна творчість, що теж надихала молодих митців на естетичні пошуки. Синтезувавши у своїй уяві найрізноманітніші художні явища, вони зважилися на протистояння “найпередовішому методу” - соціалістичному реалізму - і дали українській культурі нове, оригінальне, розмаїте мистецтво. Поштовхом для духовного пробудження стала стаття О. Довженка “Мистецтво живопису і сучасність", опублікована в червні 1955 року в “Литературной газете”, у якій автор закликав до вільного творчого пошуку та розширення стильових меж мистецтва поза офіційним методом соцреалізму. Найголовнішою відзнакою культури даного періоду стала творча індивідуальність, неповторність, взаємна несхожість.

Парадоксально те, що в Україні традиційне мистецтво, що не вписувалось у рамки соцреалізму стало нонконформістським. Митці 60-х років заново відкривали значення таких категорій, як творча особистість, цінність власного погляду на життя, індивідуального досвіду, не затьмареного ані ідеологічними догмами, ані естетичними нормативами. Причому характерні риси нонконформізму пронизують усі сфери культури: музику, літературу, кінематограф, науку, філософію, образотворче мистецтво, театр. Особливість українського нонконформізму була в довірливому, інтимному зверненні до людини. До українського нонконформізму можна віднести в мистецтві: в Києві-художників А. Суммар, В. Ламах, Г.Гавриленко, А. Лимарєва, А. Левич, І. Марчук, Ф. Гуменюк, О. Дубовик, А. Горську; у Львові - Р. Сельського, К. Звіринського зі своїми школами; “неформальну академію” Ф. Манайла з Ужгорода, В. Макаренко з Дніпропетровська; художників-нонконформістів Одеси - О. Ануфрієва, В. Стрельникова, Л. Ястреб, В. Маринюк, В. Басанець, В. Хрущ, С. Сичова, О. Соколова; новаторські ідеї в літературі спостерігаються у творчості Г. Тютюнника, Є. Сверстюка; в поезії - у творчості І. Драча, Б. Нечерди, Л. Костенко, В. Стуса; в театрі - в роботах Д. Лідера, М. Івницького; в музиці - у В. Годзяцького, Л. Грабовського, В. Губи, Ю. Іщенко, В. Сільвестрова, С. Станковича; в кінематографії - у С. Параджанова, К. Муратової, Ю. Іллєнко; в хореографічному мистецтві - у С. Лифаря. Мистецтво ставало українським, пов'язаним 3 національною й етичною традицією, і водночас глибоко новаторським, модерним, а відтак європейським. 


\section{ЕТНОМЕНТАЛЬНИЙ АСПЕКТ УКРАЇНСЬКОЇ ХУДОЖНЬОЇ КУЛЬТУРИ 60-Х РОКІВ ХХ СТОЛТТЯ}

Зберігаючи здебільшого реалістичну манеру творчості, використовуючи усталені фольклорні традиції молоді митці створюють нові художні образи. Виразником ідей, настроїв, почуттів цілого покоління, стала поезія, проголосивши своїм героєм - людину у контексті складних історичних ситуацій, спричинених кривдою, несправедливістю, приниженням національної і людської гідності. Любов до України, вболівання за долю народу, оспівування людських почугтів, природи та рідного краю стає основним змістом їх творів ("Україні", “Україно, п’ю твої зіниці” В. Симоненка, “Мандрівки серця” Л. Костенко, “Соняшник” I. Драча та ін.). Своєрідного перетворення у професійному мистецтві набула давня традиція українського народного живопису, що проявилося у використанні яскравої символіки, різноманітних художніх засобів та технік вітражу, мозаїки, фрескового живопису, кольорового скла та інших нових матеріалів. Поряд із висвітленням героїзму і патріотизму народу відбувалося освоєння сучасної тематики (основа якої - людина, їі настрої, почуття, переживання), оспівувалося розмаїття української природи. Найважливішою рисою українського мистецтва другоїполовини ХХ століття став розвиток різних культурних ареалів. Це позначилося на жанрі пейзажу, конкретному баченні художниками розмаїття української природи. Визначальними рисами творчості Т. Голембієвської, Н. Муравської, Т. Яблонської $\epsilon$ поетичність, прозорість, народність, багатство засобів виразності. Лариса Гонтова стверджує, що в 60-ті роки яскравого втілення набув неофольклорний напрям, чітко виражений у зображенні побуту. Народний дух, народний образ зливався з уявленням про духовну силу, свіжість почуттів. Декоративність, опуклість першого плану - все це $\epsilon$ характерним для творів неофольклорного напряму [1, 30]. Новими творчими здобутками відзначається в цей час талант прекрасної художниці Т. Яблонської, яка демонструє новий стиль створення синтетичних образів на основі давніх традицій українського народного живопису. Разом з В. Зарецьким вона засновує фольклорний напрям в українському образотворчому мистецтві.

Чітко окреслює протестний потенціал у мистецтві 60-х. Роман Корогодський, мимоволі порушуючи “літературоцентричний” міф шістдесятництва та наголошуючи, що феномен був значно глобальнішим і роль художників, скульпторів, режисерів, композиторів в оновленні мови мистецтва була далеко не меншою. Не випадково автор порівнює роль тодішніх художників із роллю бойчукістів та авангарду 20-х. [4].
Одним із найпотужніших напрямів відновлення національного духу й української самосвідомості стає кінематограф,відроджуючизаснованеО.Довженком українське поетичне кіно (С. Параджанов, Л. Осика, Ю. Іллєнко). Визначаючи поетичне кіно як базову модель українського авторського кінематографа, Галина Погребняк, стверджує, що “представники української моделі авторського кіно, освоюючи національну культуру, традиції, звичаї свого народу, прагнули представити таку систему художніх образів, яка би давала можливість проникати в причини явищ, встановлювати їх взаємозв'язок, розкривати межі людських почуттів, переживань, характерів, ментальних відносин, чинити опір соціальній несправедливості" [10, 99]. Нове імпресіоністичне кінозмалювання розкриває реалії життя зі справжнім національним забарвленням, високим поетичним духом, віртуозною режисерською технікою ("Тіні забутих предків" С. Параджанова, “Вечір на Івана Купала”Ю. Іллєнка та ін.). А. Бурий наголошує на взаємопов’ язаності кіномистецтва і філософії екзистенціалізму [3, 127]. У музиці даного історичного періоду відроджуються традиції, започатковані зокрема Борисом Лятошинським. Переосмислення українського фольклору, звернення до стародавніх жанрів, вияв інтересу до людей, до духу народного спостерігаємо у творчості Л. Дичко, М. Скорика, I. Карабиця, В. Годзяцького, Л. Грабовського, В. Губи, В. Сильвестрова та ін. (докладніше див.:[6]).

На думку С. Мезіної у 60-х роках XX століття розпочався новий етап українського культурного відродження, позначеного опорою на національні традиції, витоками якої $є$ епоха українського бароко та “Розстріляне відродження". Кращі представники покоління шістдесятників своєю творчістю та громадською діяльністю боролися за порятунок української нації, сприяли посиленню етнічної свідомості українців, відродженню їх духовності, культури та мови [9, 254].

Висновки. Таким чином умови розвитку української художньої культури у 60-х роках ХХ століття позитивно вплинули на духовну атмосферу, стимулювали творче і культурне життя, сприяли підвищенню інтересу до історії України, культури та традицій, звичаїв, мови. В основі світоглядних засад шістдесятництва лежить визнання свободи в усіх іiї виявах: свобода совісті, свобода мислення, свобода нації. Одним із джерел творчості був український фольклор, зокрема митцями активно запозичувалися i переосмислювалися фольклорні мотиви й образи, використовувалися народнопісенні засоби і прийоми образотворення. Отже, не зважаючи на 
державну настанову щодо формування в суспільній свідомості тези про однаковість всіх “радянських людей”, специфіка української ментальності, основною настановою якої $\epsilon$ “кордоцентричність”, спричинила звернення до нераціонального, несвідомого елемента в самому феномені. Для повноцінної суспільної і культурної інтеграції в цивілізаційний простір ментальні чинники є критерієм зацікавленості одного етносу при засвоєнні культурно-інтелектуальних надбань іншого, а також засобом для власного духовного збагачення. Тому входження України в світове цивілізаційне коло не заперечує українську самобутність, а відбувається шляхом інтеграції етнічних та загальнолюдських цінностей і смислів.

Перспективи подальшого дослідження полягають у предметному аналізі творчого доробку шістдесятників крізь призму етноментального аспекту проблеми, що допоможе більш широко й грунтовно дослідити це унікальне культурно-мистецьке явище.

\section{ЛІТЕРАТУРА}

1. Бажан О., Данилюк Ю. Опозиція в Україні (друга половина 50-х - 80-ті рр. ХХ ст.). / НАН України. Інститут історії України. - К.: Рідний край, 2000. - 616 с.

2. Білокінь С. Клуб творчої молоді “Сучасник” (1960-1965) / Сергій Білокінь. - К.: Вид дім “Києво-Могилянська академія", 2012. - 63 с.

3. Бурий А. Кінематографічні метафори історії як дзеркало європейської ідентичності / Андрій Бурий // Наукові записки. Серія "Культурологія". - Острог: Вид-во Національного університету “Острозька академія”, 2014. - Випуск 15. C. $122-142$.

4. Корогодський Р. Брама світла: Шістдесятники / Роман Корогодський. - Львів: Видавництво Українського Католицького Університету, 2009. $655 \mathrm{c}$.

5. Гонтова Л. Українське мистецтво. II половина XX ст. / Лариса Гонтова. - К.: Ред. загальнопед. газ., 2005. - 112 с.

6. Городецька О. В. Українська музика 60-х років ХХ століття у контексті цілісності епохи: дис. ... канд. мистецтвознавства: спец. 17.00.03 "Музичне мистецтво" / Оксана Валентинівна Городецька. - К., 2008. - 207 с.

7. Краснянська Н. Д. Значення рухушістдесятників усправівідродженнядержавностіУкраїни/Н.Д.Краснянська // Інтелігенція і влада : зб. наук. статей. - Одеса, 2006. - С. 88-96.

8. Костюк Л. Індивідуалізм української ментальності як суспільний феномен / Лариса Костюк // Проблеми гуманітарних наук: Збірник наукових праць Дрогобицького державного педагогічного університету імені Івана Франка / Ред. кол. Т.Біленко (гол. ред.) та ін. - Дрогобич: Редакційно-видавничий відділ ДДПУ імені Івана Франка, 2011. - Випуск двадцять сьомий. Філософія. - С. 35 - 44.

9. Мезіна С. Національна традиція в українському авангарді 1960-х років: до постановки проблеми / Світлана Мезіна // Мистецтвознавчі записки: Зб. наук. праць. - Вип. 27. - К. : Міленіум, 2015. - 428 с. - С. 246-254.

10. Погребняк Г. П. Поетичне кіно як базова модель українського авторського кінематографа / Г. П. Погребняк // Культурно-мистецьке середовище: творчість та технології: збірник матеріалів Восьмої Міжн. наук.-творчої конф., м. Київ, 16 квітня 2015 р. - К.: НАКККіМ, 2015. - C. 98-101.

11. Філософський енциклопедичний словник. К. : “Абрис”, 2002. - 744 с.

\section{REFERENCES}

1. Bazhan, O. \& Danyliuk, Yu. (2000). Opozytsiia $v$ Ukraini (druha polovyna 50-kh - 80-ti rr. XX st.) [Opposition in Ukraine (from the second half of the 50 s to the 8 's of the $20^{\text {th }}$ century)]. Kyiv: Ridnyi krai Publ., 616 p. [in Ukrainian].

2. Bilokin, S. (2012). Klub tvorchoi molodi "Suchasnyk" (1960-1965) [Club of creative youth "Contemporary" (1960-1965)]. Kyiv: Vyd. dim "Kyievo-Mohylianska akademiia”, 63 p. [in Ukrainian].

3. Buryi, A. (2014). Kinematohrafichni metafory istorii yak dzerkalo yevropeiskoi identychnosti [Cinematic metaphors of history as a mirror of European identity]. Scientific notes. Series "Culturology". Ostroh: Vyd-vo Natsionalnoho universytetu "Ostrozka akademiia”, vol. 15, pp. 122 142. [in Ukrainian].

4. Korohodskyi, R. (2009). Brama svitla: Shistdesiatnyky [The gate of light: The sixties]. Lviv: Vydavnytstvo Ukrainskoho Katolytskoho Universytetu, 655 p. [in Ukrainian].

5. Hontova, L. (2005). Ukrainske mystetstvo. II polovyna XX st. [Ukrainian art. The second half of the $20^{\text {th }}$ century]. Kyiv: Red. zahalnoped. haz., 112 p. [in Ukrainian].

6. Horodetska, O. V. (2008). Ukrainska muzyka 60-kh rokiv XX stolittia u konteksti tsilisnosti epokhy [Ukrainian music of the $60 \mathrm{~s}$ of the $20^{\text {th }}$ century in the context of the era integrity]. Candidate's thesis. Kyiv, 207 p. [in Ukrainian].

7. Krasnianska, N. D. (2006). Znachennia rukhu shistdesiatnykiv u spravi vidrodzhennia derzhavnosti Ukrainy [The significance of the sixties' movement 
in the rebirth of the statehood of Ukraine]. Intellectuals and power: collection of scientific articles. Odesa, pp. 88-96. [in Ukrainian].

8. Kostiuk, L. (2011). Indyvidualizm ukrainskoi mentalnosti yak suspilnyi fenomen [Individualism of Ukrainian mentality as a social phenomenon]. Problems of the humanitarian sciences: Collection of scientific works of Drohobych State Pedagogical University named after Ivan Franko. Drohobych: Redaktsiino-vydavnychyi viddil DDPU imeni Ivana Franka, vol. 27. Filosofiia, pp. 35-44. [in Ukrainian].

9. Mezina, S. (2015). Natsionalna tradytsiia v ukrainskomu avanhardi 1960-kh rokiv: do postanovky problemy [National tradition in the Ukrainian avantgarde of the 1960s: to the problem propose]. Art studies notes: Collection of scientific works, vol.
27. Kyiv: Milenium Publ., 428 p., pp. 246-254. [in Ukrainian].

10. Pohrebniak, H. P. (2015). Poetychne kino yak bazova model ukrainskoho avtorskoho kinematohrafa [Poetic cinema as the basic model of Ukrainian author's cinematography]. Kulturno-mystetske seredovyshche: tvorchist ta tekhnolohii: zbirnyk materialiv Vosmoi Mizhn. nauk.-tvorchoi konf., m. Kyiv, 16 kvitnia $2015 \mathrm{r}$. - Cultural and artistic environment: creativity and technologies: Collection of materials of the 8th International Scientific and Creative Conference, (pp. 98-101). Kyiv, April 16, 2015. Kyiv: NAKKKiM Publ. [in Ukrainian].

11. Filosofskyi entsyklopedychnyi slovnyk (2002). [Philosophical encyclopedic dictionary]. Kyiv: Abrys Publ., 744 p. [in Ukrainian].

Стаття надійшла до редакції 23.07.2018

УДК 130.1

DOI:

Валентина Дротенко, кандидат філософських наук, дочент, завідувач кафедри культурології та мистецької освіти Дрогобииького державного педагогічного університету імені Івана Франка

\section{ПАРАДИГМА КОНЦЕПТУ “СУБ'ЄКТНІСТЬ”}

У статті розглянуто філософський дискурс конщепту “суб'єктність” в сучасних некласичних філософських студіях. Проведено аналіз філософських прачь вітчизняних та зарубіжснх авторів з проблем концептуального мислення та конщепту “суб 'єктність”. Встановлено відмінність концепту “суб 'єктність”, від поняття “суб'єктивність"; виявлено взаємозв'язок концепту “суб'єктність” з архетипом “самість"; визначено парадигму суб'єктності як “модального оператора” особистості.

Ключові слова: метафізика; парадигма; концепт; концептивізм; суб'єктивність; суб 'єктність.

Jim. 13.

Valentyna Drotenko, Ph.D.(Philosophy), Associate Professor, Head of the Culturology and Artistic Education Department Drohobych Ivan Franko State Pedagogical University

\section{THE PARADIGM OF THE CONCEPT "SUBJECTIVITY"}

The article deals with the philosophical discourse of the concept "subjectivity" in modern non-classical philosophical studies. The analysis of philosophical works of domestic and foreign authors on the problems of conceptual thinking and the concept of "subjectity" is carried out. The difference between the concept "subjectivity" and the notion "subjectiveness" is established; the relationship between the concept of "subjectivity" and the archetype "self" is revealed; defined paradigm of subjectivity as a "modal operator" of personality.

It is revealed that contemporary philosophical reflection understands the phenomenon of subjectivity as a special personal quality, which is connected with active and transformative abilities of the individual and outlines the procedural nature of self "I": self-consciousness, self-determination, self-regulation, subjectification, etc.

It is noted that all the existence of an individual is closed in the subjective sphere, but being is not subjective, but subjectivist. The analysis of the historical and philosophical content of the phenomenon of subjectivity allowed to define the concept of "subjectivity" as a specific "modal operator" of personality (necessity, possibility, reality) and to discover the trajectory of the subject's activity of the individual. In particular, this is: self-awareness - a reflection of free will in a particular time-space; self-determination - choice and decision making in order to harmonize the problem of reality; self-realization model-interactivity of the methods of interaction and performance of the results of activity.

Keywords: metaphysics; a paradigm; a concept; conceptualism; subjectivity; subjectiveness.

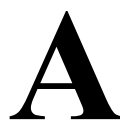

ктуальність проблеми. Серед головних онтолого-метафізичних проектів сучасності - розробка метафізики з акцентом на науково-логічну, методолого-діалектичну, літературно-естетичну і релігійно-етичну проблематики та виявлення в 